E-ISSN : 2549-6581

DOI: 10.21776/ub.JOIM.2019.003.02.1

Artikel Hasil Penelitian

Diterima : 2 Juli 2018

Direview : 4 Juli 2019

Dimuat : Agustus 2019 - November 2019
OPEN ACCESS

Journal of Issues in Midwifer

\title{
Perbedaan Antara Asupan Vitamin B1, B6 dan B12 dengan Kejadian Dysmenorrhea pada Remaja Putri di SMAN 8 Kota Malang dan MA Nurul Ulum Munjungan Kabupaten Trenggalek
}

\author{
Tiara Dewi Pratiwi ${ }^{1)}$, Rismaina Putri ${ }^{2}$, Catur Saptaning Wilujeng ${ }^{3}$ \\ 1) Program Studi $S 1$ Kebidanan, Fakultas Kedokteran, Universitas Brawijaya \\ Tiarapratiwi560@gmail.com, TIp: +6285721303756 \\ ${ }^{2}$ Program Studi S1 Kebidanan, Fakultas Kedokteran, Universitas Brawijaya, Email: \\ rismaina.putri@gmail.com \\ ${ }^{3}$ Program Studi IImu Gizi, Fakultas Kedokteran, Universitas Brawijaya, Email: \\ catursaptaning@gmail.com
}

\begin{abstract}
Dysmenorrhea is one of the most frequent problemsby young women in menstrual period. Dysmenorrhea is divided into primary dysmenorrhea and secondary dysmenorrhea. Primary dysmenorrhea occurs without pelvic organ pathology.Micronutrient deficiency of vitamin B1, B6 and B12 is factor of primary dysmenorrhe. Consum of the three vitamins daily can prevent primary dysmenorrhe because the vitamins are able to inhibit prostaglandin synthesis. This study aims to determine the difference between intake of vitamins $B 1, B 6$ and $B 12$ with the incidence of primary dysmenorrhea in adolescent of SMAN 8 Malang and MA Nurul Ulum Munjungan. Design of this study was analytic using cross sectional method. The sample in this study amounted to 84 people were selected using stratified random sampling. Analitic testing of relationship betwen intake of Vitamin $B 1, B 6$ and $B 12$ with primary dysmenorrhea using Spearman Rank test and Linear Regression. The results shows $p<0.05$ for therelationship betwen intake of Vitamin B1, B6 and B12 with primary dysmenorrhea. The result of Linear regression obtained $p<0.05$. Difference testing show the difference between intake of vitamins B1, B6 and B12 from both schools performed using Mann-Whitney. The results showed that $p>0.05$. It can be concluded that there is no difference in vitamin $B 1$, B6 and B12 intake from SMAN 8 Malang and MA Nurul Ulum Munjungan, but the most influential micronutrient substances of the two schools are different. Vitamin B12 is the most influential vitamin in SMAN 8 Malang, while in MA Nurul Ulum Munjungan is Vitamin B1.
\end{abstract}

Keywords: Dysmenorrhea, High School Students, Vitamin B1, Vitamin B6, Vitamin B12, Young Women

\section{ABSTRAK}

Dysmenorrhea merupakan salah satu masalah menstruasi yang paling sering dialami oleh remaja putri. Dysmenorrhea dibagi menjadi dysmenorrhe primer dan sekunder. Dysmenorrhea terjadi tanpa disertai patologi organ pelvik. Kekurangan mikronutrien yakni vitamin B1, B6 dan B12 merupakan salah satu faktor penyebab dari 
dysmenorrhe primer. Konsumsi seimbang dari ketiga vitamin pada menu harian dapat mencegah terjadinya dysmenorrhe primer karena ketiga vitamin ini mampu menghambat sintesa prostaglandin. Penelitian ini bertujuan untuk mengetahui perbedaan antara asupan vitamin B1, B6 dan B12 dengan kejadian dysmenorrhea pada remaja di SMAN 8 Kota Malang dan MA Nurul Ulum Munjungan, Trenggalek. Desain penelitian yang digunakan adalah observasional analitik menggunakan metode cross sectional. Sampel dalam penelitian ini berjumlah 84 orang yang dipilih dengan menggunakan teknik proportional stratified random sampling. Uji analisis hubungan asupan Vitamin B1, B6 dan B12 dengan kejadian dysmenorrhea menggunakan uji Spearman Rank dan Regresi Linier. Hasil uji Spearmandiperoleh nilai $p<0,05$ untuk hubungan asupan Vitamin B1, B6 dan B12 dengan kejadian dysmenorrhea. Hasil analisis Regresi Linier diperoleh $p<0,05$. Uji beda dilakukan untuk melihat adanya perbedaan antara asupan vitamin B1, B6 dan B12 dari kedua sekolah dilakukan menggunakan uji Mann-Whitney. Hasil uji menunjukkan $p>0,05$. Sehingga dapat disimpulkan bahwa tidak ada perbedaan asupan vitamin B1, B6 dan B12 dari SMAN 8 Kota Malang dan MA Nurul Ulum Munjungan, akan tetapi zat mikronutrien yang paling berpengaruh dari kedua sekolah berbeda. Vitamin B12 merupakan vitamin yang paling berpengaruh di SMAN 8 Kota Malang, sedangkan di MA Nurul Ulum Munjungan Vitamin B1 yang paling berpengaruh.

Kata kunci: Remaja Putri, Dysmenorrhea, Siswi SMA, Vitamin B1, Vitamin B6, Vitamin B12

*Korespondensi:Tiara Dewi Pratiwi Surel: tiarapratiwi560@gmail.com

\section{PENDAHULUAN}

Masa remaja merupakan masa peralihan dari masa kanak-kanak menuju dewasa. Pada masa ini terjadi proses transisi atau pubertas yang ditandai dengan terjadinya perubahan dalam fisik, psikis, dan sosialnya. Pubertasdiartikan sebagai periode dalam proses pematangan seksual dengan hasil tercapinya kematangan organ reproduksi yang ditamdai dengan terjadinya menstruasi. ${ }^{1}$

Menstruasi adalah luruhnya lapisan endometrium yang terjadi karena tidak terbuahinya ovum. Menstruasi dengan durasi 3-7 hari. siklus menstruasi normal rata-rata adalah 28 hari, tetapi siklus bisa mencapai 35 hari atau bahkan lebih pendek yairu 21 hari. $^{1}$

Pada sebagian besar wanita yang mengalami menstruasi akan merasakan ketidaknyamanan berupa nyeri haid atau yang disebut dysmenorrhea. Jumlah dari remaja putri di Indonesia dari data BKKBN tahun $2010 \quad$ menunjukkan 21.489 .600 atau $18,11 \%$ dari jumlah perempuan. Kejadian dysmenorrhea di Indonesia 55\% terjadi pada perempuan usia produktif. ${ }^{2}$

Terdapat beberapa faktor risiko dari dysmenorrhea yakni usia menarche, aktivitas fisik, status gizi, asupan gizi dan riwayat keluarga. Vitamin B komplek (vitamin B1 , B6 dan B12) dalam beberapa literatur dikatakan dapat meringankan gangguan menstruasi malalui penghambatan pada Cyclooksigenase (COX) dan Lipoksigenase (LOX) sehingga menghambat sintesis prostaglandin dan leukotrien yang memicu timbulnya dysmenorrhea. ${ }^{3}$

Mekanisme Vitamin B1 dalam mengurangi nyeri dengan menghambat biosintesis prostaglandin dan menekan COX (Cyclo-oxygenase) melalui penghambatan aktivasi post 
translasi COX sehingga akan menghambat produksi prostaglandin. ${ }^{4}$

Vitamin B6 berperan dalam melawan inflamasi dengan meningkatkan aktivasi reseptor prostasiklin yang berperan dalam vasodilatasi pembuluh darah, menurunkan sintesis tromboksan dan prostaglandin, serta menghambat agregasi platelet. ${ }^{5,6}$

Sumber vitamin B1 , B6, dan B12 dapat kita peroleh dari sumber bahan makanan yaitu: pada hati sapi, hati unggas, daging sapi maupun unggas, ikan dan bahan makanan laut lain, kacangkacangan, polong-polongan, bijibijian, dan sayuran. Melihat dari berbagai sumber bahan pangan dan kandungan vitamin B komplek dari United States Department of Agricultural Food Composition Databases kandungan vitamin B kompleks tinggi pada bahan makanan laut seperti ikan, rumput laut dan kerang sehingga peneliti ingin membandingkan antara asupan vitamin B komplek pada remaja putri yang ada di perkotaan dan yang berada di daerah pesisir pantai. Selain itu juga penjelasan mengenai hubungan asupan nutrisi vitamin B terhadap kejadian dysmenorrhea juga masih terbatas.

Hasil studi pendahuluan yang dilakukan di SMA 8 Kota Malang menunjukkan terdapat $(77,7 \%)$ siswi kelas X-XI yang mengalami dysmenorrhe primer, sedangkan di MA Nurul Ulum Munjungan terdapat $(52,2 \%) \quad$ siswi yang mengalami dysmenorrhe primer. $\mathrm{Hal}$ ini mendorong peneliti untuk mengetahui lebih dalam mengenai perbedaan antara asupan Vitamin B1, B6 dan B12 dengan kejadian dysmenorrhe primer dan perbedaan asupan Vitamin B1, B6 dan B12 dari kedua sekolah tersebut.

METODE PENELITIAN Rancangan/Desain Penelitian

Desain penelitian ini adalahobservational analytic menggunakan metode cross sectional untuk melihat perbedaan antara variabel bebas asupan makanan yang mengandung Vitamin B1, B6 dan B12 dengan variabel terikat yaitu kejadian dysmenorrhe primer di SMAN 8 Kota Malang dan MA Nurul Ulum Munjungan

\section{Sumber Data}

Data asupan Vitamin B1, B6 dan B12 serta data kejadian dysmenorrhea didapatkan dari hasil wawancara yang dilakukan oleh enumerator.

\section{Sasaran Penelitian}

Populasi dalam penelitian ini menggunakan remaja putri berusia 15-18 tahun dari SMAN 8 Kota Malang dan MA Nurul Ulum Munjungan Trenggalek kelas $X$ dan $X I$. Dalam penelitian ini sampel diambil menggunakan teknik proportional stratified random sampling dan jumlah total sampel dari kedua seklah adalah 85 .

\section{Pengembangan Instrumen dan Teknik Pengumpulan}

Peneliti melakukan studi pendahuluan terlebih dahulu untuk mengetahui prosentase kejadian dysmenorrhea dan untuk mengetahui bahan makanan sumber vitamin B1, B6, dan B12 yang paling sering dikonsumsi oleh siswi di SMAN 8 Kota Malang dan MA Nurul Ulum Munjungan Kabupaten Trenggalek. 
Setelah srat kelayakan etik diterima oleh peneliti, selanjutnya peneliti melakukan perizinan, perkenalan dan juga menjelaskan tujuan penelitian ke SMAN 8 Kota Malang dan MA Nurul Ulum Munjungan Kabupaten Trenggalek. Setelah pihak sekolah memberi izin, peneliti melakukan pembagian lembar skrining sample untuk mencari responden dengan kriteria sesuai kriteria penelitian. Setelah pengambilan data selesai peneliti melakukan proses editing guna memastikan bahwa seluruh lembar terisi.

Data tersebut kemudian disesuaikan dengan kriteria insklusi dari penelitian. Setelah didapatkan nama-nama responden yang sesuai dengan kriteria, peneliti memberikan lembar penjelasan penelitian beserta lembar persetujuan responden/informed consent dan lembar identitas kepada seluruh siswi dari kelas X-XI tahun ajaran 2017/2018 di SMAN 8 Kota Malang dan 162 siswi di MA Nurul Ulum Munjungan Kabupaten Trenggalek untuk dimintakan izin dari orangtua/wali murid yang menyatakan siswi tersebut diperbolehkan mengikuti penelitian atau tidak dan dikumpulkan kembali lembar informed consent dan biodata 2-3 hari setelahny. Selanjutnya editing untuk memastikan semua lembar sudah terisi dan melakukan pengelompokan berdasarkan perizinan dari orangtua/wali murid (informed consent ditandatangani orangtua/wali murid atau tidak).

Siswi yang telah mendapatkan izin dari orang tua nama-namanya akan didaftar dan selanjutnya dilakukan teknik sampling. Setlah didapatkan kode-kode responden, peneliti kemudian menghubiungi responden secara personal untuk membuat jadwal pengambilan data.

Peneliti meminta izin untuk melakukan pengambilan data di SMAN 8 Kota Malang dan MA Nurul Ulum Munjungan Kabupaten Trenggalek pada hari dan tanggal yang telah disepakati dengan pihak sekolah maupun responden dalam penelitian.

Peneliti mengumpulkan responden penelitian di ruangan yang disediakan pihak sekolah untuk mempermudah dalam pengambilan data karena kondisi ruangan lebih tenang.Peneliti menjelaskan kembali prosedur penelitian, tujuan penelitian serta memperkenalkan enumerator yang akan melakukan wawancara dengan responden untuk mendapatkan data asupan vitamin B1, B6, dan B12 dari konsumsi makanan harian selama 1 bulan yang lalu.

Enumerator yang membatu peneliti untuk melakukan pengambilan data adalah lulusan S1 Program Studi IImu Gizi Fakultas Kedokteran Universitas Brawijaya Malang sejumlah 8 orang. Waktu penelitia yang diperlukan dalam sesi wawancara $1 \times 30$ menit, dan dilakukan setelah pulang sekolah pada hari yang telah disepakati.Mengumpulkan data dari responden dengan bantuan enumerator untuk mengisi form SQFFQ mengenai pola makan yang dibantu dengan food model photo. Enumerator yang membatu dalam proses pengambilan data asupan vitamin B1, B6, dan B12sudah memperoleh materi dan praktek dietary assesment intake makan.

Peneliti menggunakan Form SQ-FFQ untuk melihat asupan vitamin B1, B6, dan B12 dan 
dilanjutkan denganmelakukan editing untuk memastikan semua lembar sudah terisi. Selanjutnya peneliti melakukan analisis data.

\section{Teknik Analisis Data}

1. Analisis Univariat

Deskripsi karakteristik dari responden dan mengetahui gambaran dari masing-masing variabel. Analisis ini menghasilkan distribusi dan presentasi setiap variabel. Tujuan dari analisis univariat adalah untuk menjelaskan karakteristik masing-masing variabel yang diteliti.

\section{Analisis Bivariat}

Melihat dan mengetahui kemaknaan dan besarnya hubungan antara asupan zat gizi mikro yaitu vitamin B1, B6, dan B12dengan kejadian dysmenorrhea. Analisis yang digunakan utuk melihat kemaknaan dan besarnya hubungan antara vitamin B1,B6 dan B12 dengan kejadian dysmenorrhea menggunakan uji Spearman. Hasil analisis uji Spearman akan memperlihatkan besar pengaruh dan arah hubungan.

Uji Regresi Linier digunakan untuk melihat faktor mikronutrien yang memiliki pengaruh paling besar terhadap kejadian dysmenorrhea. Kemudia guna melihat adanya perbedaan asupan bahan makanan tinggi Vitamin B1, B6 dan B12, digunakanlah uji MannWithney. Uji ini akan memberikan gambaran ada tidaknya asupan bahan makanan tinggi Vitamin B1, B6 dan B12 dari kedua sekolah.

\section{HASIL PENELITIAN}

Responden terbagi menjadi 3 kelompok usia, yaitu 15 tahun, 16 tahun, dan 17 tahun. Berdasarkan hasil analisis, diperoleh gambaran responden sebagai berikut : di SMAN 8 Kota Malang terdapat $51,8 \%$ responden berusia 15 tahun, $35,7 \%$ berusia 16 tahun, dan $12,5 \%$ berusia 17 tahun. Sedangkan di MA Nurul Ulum Munjungan terdapat $14,3 \%$ responden berusia 15 tahun, $64,3 \%$ berusia 16 tahun, dan $21,4 \%$ berusia 17 tahun. 


\section{Karakteristik Responden}

Tabel 1 Gambaran Umum Responden dan Gambaran asupan vitamin B1, B6, dan B12

\begin{tabular}{|c|c|c|c|c|c|c|}
\hline & \multicolumn{3}{|c|}{ MA Nurul Ulum Munjungan } & \multicolumn{3}{|c|}{ SMAN 8 Kota Malang } \\
\hline Karakteristik & $\mathbf{n}$ & \multicolumn{2}{|c|}{$\%$} & $\mathrm{n}$ & \multicolumn{2}{|c|}{$\%$} \\
\hline \multicolumn{7}{|l|}{ Usia } \\
\hline 15 tahun & 4 & \multicolumn{2}{|c|}{14,3} & 29 & \multicolumn{2}{|c|}{51,78} \\
\hline 16 tahun & 18 & \multicolumn{2}{|c|}{64} & 20 & \multicolumn{2}{|c|}{35,71} \\
\hline 17 tahun & 6 & \multicolumn{2}{|c|}{21} & 7 & \multicolumn{2}{|c|}{12,5} \\
\hline \multicolumn{7}{|l|}{ Kelas } \\
\hline$X$ & 13 & \multicolumn{2}{|c|}{46,43} & 30 & \multicolumn{2}{|c|}{53,57} \\
\hline $\mathrm{XI}$ & 15 & \multicolumn{2}{|c|}{53,57} & 26 & \multicolumn{2}{|c|}{46,42} \\
\hline \multicolumn{7}{|c|}{ Dysmenorrhea } \\
\hline Ringan & 6 & \multicolumn{2}{|c|}{21,4} & 17 & \multicolumn{2}{|c|}{28,6} \\
\hline Sedang & 20 & \multicolumn{2}{|c|}{71,4} & 30 & \multicolumn{2}{|c|}{51,8} \\
\hline Berat & 2 & \multicolumn{2}{|c|}{7} & 9 & \multicolumn{2}{|c|}{16} \\
\hline Asupan & Vitamin & Vitamin & Vitamin & Vitamin & Vitamin & Vitamin \\
\hline Vitamin & B1 & B6 & B12 & B1 & B6 & B12 \\
\hline Kurang & 25 & 23 & 18 & 25 & 23 & 18 \\
\hline Cukup & 3 & 5 & 2 & 3 & 5 & 2 \\
\hline Lebih & 0 & 0 & 8 & 0 & 0 & 8 \\
\hline
\end{tabular}

Asupan vitamin B1 responden tergolong rendah. Sebesar 96,4\% responden dari SMAN 8 Kota Malang memiliki asupan vitamin B1 yang kurang sedangkan di MA Nurul Ulum Munjungan sebanyak $89,3 \%$ responden.

Asupan vitamin B6 sebesar 85,7\% responden dari SMAN 8 Kota Malang memiliki asupan vitamin B6 yang kurang sedangkan di di MA Nurul Ulum Munjungan sebanyak $82 \%$ responden.

Sama halnya dengan vitamin B1 dan B6 pemenuhan asupan vitamin B12, resonden dari SMAN 8 Kota Malang dan MA Nurul Ulum juga dapat dikatakan kurang. Dapat telihat dari prosentsenya yakni sebesar $82 \%$ responden dari SMAN 8 Kota Malang masuk dalam kategori kurang sedangkan dari MA Nurul Ulum Munjungan sebanyak $54 \%$ responden.
Hubungan asupan vitamin B1, B6, dan B12 dengan tingkat keparahan dysmenorrhea

Tabel 3. Hubungan asupan vitamin B1, B6, dan B12 dengan tingkat keparahan dysmenorrheaMA Nurul Ulum Munjungan

\begin{tabular}{ll}
\hline & $\begin{array}{l}\text { Tingkat } \\
\text { Keparahan } \\
\text { Dysmenorrhea }\end{array}$ \\
& \\
\hline Asupan Vitamin B1 & $\begin{array}{l}\mathrm{p}=0,008 \\
\mathrm{r}=-0,493 \\
\mathrm{n}=28\end{array}$ \\
Asupan Vitamin B6 & $\mathrm{p}=0,015$ \\
& $\mathrm{r}=-0,455$ \\
& $\mathrm{n}=28$ \\
Asupan $\quad$ Vitamin & $\mathrm{p}=0,005$ \\
B12 & $\mathrm{r}=-0,520$ \\
& $\mathrm{n}=28$ \\
uji Spearman & \\
\hline
\end{tabular}


Berdasarkan tabel di atas dapat disimpulkan bahwa terdapat hubungan antara vitmain B1 dengan kejadian dysmenorrhea. Semakin tinggi asupan vitamin B1 semakin rendah skor dyemnorrhea primer dengan kekuatan hubungan lemah dan memiliki arah negatif.

Berdasarkan tabel diatas vitamin B6 dengan kejadian dysmenorrhea menunjukkan adanya hubungan yang bersifat lemah dan memiliki arah hubungan negatif.

Kemudian untuk hubungan asupan vitamin B12 dengan kejadian dysmenorrhea menunjukkan adanya hubungan yang cukup kuat dan memiliki arah hubungan negatif.

Tabel 4. Hasil Regresi Linier

\begin{tabular}{lll}
\hline Variabel & $p$ & $r$ \\
\hline Asupan Vitamin B1 & 0,006 & $-0,509$
\end{tabular}

Uji regresi linier

Berdasarkan hasi uji pada tabel 5.7 maka dilakukan analisis multivariat dan hasil analisis data secara regresi linier pada (tabel 4.) didapatkan hasil bahwa asupan yang paling memengaruhi tingkat keparahan dysmenorrhea di MA Nurul Ulum Munjungan adalah asupan Vitamin B1 dengan persamaan $Y=5,877+(-2,880) \times$ asupan vitamin $B 1$.

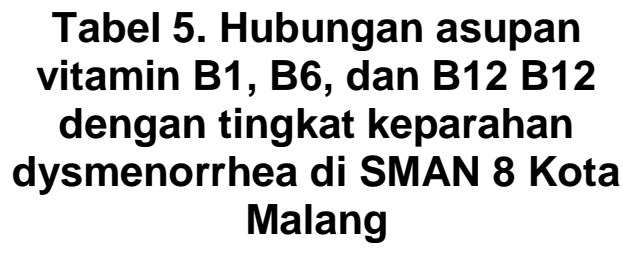

\begin{tabular}{ll}
\hline & $\begin{array}{l}\text { Tingkat } \\
\text { Keparahan } \\
\text { Dysmenorrhea }\end{array}$ \\
\hline Asupan Vitamin B1 & $\mathrm{p}=0,001$ \\
& $\mathrm{r}=-0,432$ \\
& $\mathrm{n}=56$ \\
\hline Asupan Vitamin B6 & $\mathrm{p}=0,003$ \\
& $\mathrm{r}=-0,384$ \\
& $\mathrm{n}=56$ \\
\hline Asupan & $\mathrm{p}=0,000$ \\
B12 & $\mathrm{r}=-0,466$ \\
& $\mathrm{n}=56$ \\
\hline uji Spearman &
\end{tabular}

Berdasarkan tabel di atas dapat disimpulkan bahwa terdapat hubungan antara vitamin B1 dengan kejadian dysmenorrhea. Semakin tinggi asupan vitamin B1 semakin rendah skor dyemnorrhea primer dengan kekuatan hubungan lemah dan memiliki arah negatif.

Berdasarkan tabel diatas vitamin B6 dengan kejadian dysmenorrhea menunjukkan adanya hubungan yang bersifat lemah dan memiliki arah hubungan negatif.

Kemudian untuk hubungan asupan vitamin B12 dengan kejadian dysmenorrhea menunjukkan adanya hubungan yang bersifat lemah dan memiliki arah hubungan negatif.

Tabel 6. Hasil Regresi

Linier

\begin{tabular}{lll}
\hline Variabel & $\mathrm{p}$ & $\mathrm{R}$ \\
\hline $\begin{array}{l}\text { Asupan } \\
\text { Vitamin B12 }\end{array}$ & 0,000 & $-0,471$ \\
& &
\end{tabular}

Uji Regresi Linier 
Berdasarkan hasi uji pada tabel 5.7 maka dilakukan analisis data secara regresi linier pada tabel 5.8 didapatkan hasil bahwa asupan yang paling memengaruhi tingkat keparahan dysmenorrhea di SMAN 8 Kota Malang adalah asupan Vitamin B12 dengan persamaan $Y=$ $5,840+(-0,722) \times$

asupan vitamin $B 12$.

Uji Beda Kejadian Dysmenorrhea dengan Asupan Vitamin B1, B6 dan B12

\section{Tabel 7. Hasil Uji Beda}

Kejadian

Dysmenorrhea

\begin{tabular}{ll}
\hline $\begin{array}{l}\text { Asupan } \\
\text { Vitamin B1 }\end{array}$ & $\mathrm{p}=0,418$ \\
\hline $\begin{array}{l}\text { Asupan } \\
\text { Vitamin B6 }\end{array}$ & $\mathrm{p}=0,760$ \\
\hline $\begin{array}{l}\text { Asupan } \\
\text { Vitamin B12 }\end{array}$ & $\mathrm{p}=0,097$ \\
\hline Uji Mann-Whitney &
\end{tabular}

Berdasarkan hasil analisis tidak ada beda antara MA Nurul Ulum Munjungan dan SMAN 8 Kota Malang terkait asupan mikronutrien B1, B6, dan B12 dengan kejadian dysmenorrhea, tetapi terdapat perbedaan zat gizi mikro yang paling berpengaruh pada kedua sekolah. Pada MA Nurul Ulum Munjungan zat gizi mikro yang paling berpengaruh adalah B1 sedangkan di SMAN 8 Kota Malang zat gizi mikro yang paling berpengaruh adalah vitamin B12.

\section{PEMBAHASAN}

\section{Analisis Karakteristik Umum Responden}

MA Nurul Munjungan Trenggalek merupakan sekolah di Munjungan dengan kejadian dysmenorrhea tinggi. Pada tahun ajaran 2017/2018 jumlah siswi di
MA Nurul Ulum Munjungan yaitu 162 siswi. Siswi yang bergabung dalam penelitian ini sebanyak 28 siswi dari kelas sepuluh dan sebelas. Usia responden terbagi dalam tiga kelompok, yaitu usia 15 tahun, 16 tahun, dan 17 tahun. Sebanyak $14,3 \%$ responden berusia 15 tahun, $64,3 \%$ berusia 16 tahun, dan $21,4 \%$ berusia 17 tahun.

SMAN 8 Malang merupakan sekolah yang memiliki angka kejadian dysmenorrhea tinggi di Kota Malang. Pada Tahun ajaran 2017/2018 jumlah 338 siswi. Siswi yang bergabung dalam penelitian ini sebanyak 56 siswi terbagi menjadi dua kelas sepuluh dan sebelas dari kelas Bahasa, IPA, dan IImu Sosial. Usia responden tebagi dalam tiga kelompok, yaitu usia 15 tahun, 16 tahun, dan 17 tahun. 51,8\% responden berusia 15 tahun, 35,7\% berusia 16 tahun, dan $12,5 \%$ berusia 17 tahun.

\section{Analisis Tingkat Asupan Vitamin B1, B6 dan B12}

Pemenuhan kebutuhan zat gizi makro maupun mikro orang Indonesia didasarkan pada Angka Kecukupan Gizi (AKG) tahun 2013. Pada AKG 2013 telah ditentukan jumlah zat gizi yang harus dikonsumsi seseorang berdasarkan usianya. Konsumsi Vitamin B1 pada remaja usia 15-18 tahun dikatakan cukup apabila mencapai angka 1,1 mg/hari, konsumsi Vitamin B1 dikatakan kurang jikapemenuhannya mencapai $<89 \%$ AKG atau $<0,98 \mathrm{mg} / \mathrm{hari}$ dan dikatakan lebih jika pemenuhannya mencapai $>120 \%$ AKG atau $>1,32$ $\mathrm{mg} /$ hari. Konsumsi Vitamin B6 pada remaja putri usia 15-18 tahun tergolong cukup apabila mencapai angka 1,2 $\mathrm{mg} /$ hari, kurang jika pemenuhannya mencapai $<1,07$ 
$\mathrm{mg} /$ hari dan lebih jika pemenuhannya mencapai >1,44 $\mathrm{mg} /$ hari. Sedangkan konsumsi Vitamin B12 dikatakan cukup apabila mencapai $2,4 \mathrm{mcg} / \mathrm{hari}$, kurang jika pemenuhannya mencapai $<89 \%$ AKG dan dikatakan lebih jika pemenuhannya mencapai $>120 \%$ AKG. $^{7}$

Hasil pengukuran asupan Vitamin B1 pada penelitian ini didapatkan hasil bahwa sebanyak 89\% responden dari MA Nurul Ulum Munjungan masuk dalam kategori kurang dan $12 \%$ responden masuk kategori cukup. Sedangkan untuk SMAN 8 Kota Malang sebanyak $96 \%$ responden masuk dalam kategori kurang dan hanya sebanyak 4\% masuk dalam kategori cukup.

Hasil penelitian yang dilakukan Sukmajati (2015) didapatkan hasil asupan Vitamin B1 responden tergolong kurang yaitu $97,2 \%$ dan hanya sebanyak $2,8 \%$ responden tergolong asupan cukup. Begitu pula dengan hasil penelitian yang dilakukan Muizzah (2013), responden memiliki asupan Vitamin B1 yang kurang sebesar $94,7 \%$ dan hanya $5,3 \%$ responden dengan supan Vitamin B1 yang tergolong cukup. ${ }^{8,9}$

Berdasarkan hasil yang telah dilakukan serta hasil dari beberapa penelitian terdahulu, dapat disimpulkan bahwa sebagian besar responden memiliki asupan Vitamin B1 yang tegolong kurang. Hal ini dapat terjadi karena konsumsi bahan makanan kaya Vitamin B1 dari responden kurang. Dampak dari kekurangan Vitamin B1 dapat menyebabkan seseorang mengalami gejala seperti mudah kelelahan, mudah tersinggung, melemahnya daya ingat, anoreksia, nyeri perut, dan konstipasi. ${ }^{10}$

Selanjutnya hasil yang didapatkan pada penelitian asupan Vitamin B6 pada remaja putri di MA Nurul Ulum Munjungan yang tergolong kurang sebesar $86 \%$ dan $14 \%$ responden masuk dalam kategori cukup. Sedangkan untuk SMAN 8 Kota Malang asupan Vitamin B6 dalam karegori kurang sebesar $86 \%$, $11 \%$ masuk dalam kategori cukup dan 4\% remaja putri masuk dalam kategori konsumsi Vitamin B6 lebih.

Hasil penelitian yang dilakukan Sukmajati (2015), diperoleh 58,3\% responden memiliki asupan Vitamin B6 yang kurang dan sebanyak $41,7 \%$ responden memiliki asupan Vitamin B6 yang cukup. Hasil penelitian I ainnya menunjukkan bahwa $43 \%$ responden memiliki asupan Vitamin B6 yang kurang, 25\% memiliki asupan yang cukup dan $32 \%$ responden memiliki asupan Vitamin B6 yang lebih. ${ }^{8,11}$

Berdasarkan kedua hasil penelitian tersebut dapat disimpulkan bahwa pemenuhan asupan Vitamin B6 lebih besar daripada pemenuhan Vitamin B1.. Kekurangan Vitamin B6 ini sendiri dapat disebabkan karena pemilihan makanan tinggi Vitamin B6 yang kurang. Kekurangan Vitamin B6 menyebabkan gejala-gejala seperti lemah, mudah tersinggung dan sulit tidur. Namun, kelebihan Vitamin B6 yang berlebihan selama berbulanbulan juga dapat menyebabkan kerusakan saraf permanen sehingga disarankan untuk mengonsumsi Vitamin B6 secara seimbang. ${ }^{12}$

Selanjutnya hasil yang didapatkan pada penelitian asupan Vitamin B12 pada remaja putri di 
MA Nurul Ulum Munjungan tergolong kurang 54\%, sebanyak $7 \%$ responden masuk kategori cukup dan responden yang memiliki asupan Vitamin B12 yang lebih sebesar 29\%. Asupan Vitamin B6 di SMAN 8 Kota Malang yang masuk dalam kategori kurang sebesar $82 \%$ , 4\% kategori cukup dan 14\% remaja putri masuk dalam kategori konsumsi Vitamin B12 lebih.



Berdasarkan hasil penelitian yang telah dilakukan serta hasil dari beberapa penelitian terdahulu dapat disimpulkan bahwa sebagian besar responden memiliki asupan Vitamin B12 yang tergolong kurang. Kekurangan asupan Vitamin B12 bisa terjadi dikarenakan pola makan yang tidak sehat, pemilihan makanan reponsen terhadap makanan yang mengandug Vitamin B12 kurang dan kadar asam lambung yang rendah. Rendahnya level vitamin B12 dapat menyebabkan beberapa gejala seperti mudah lelah, diare, mudah gelisan, mati rasa, dan sensasi kesemutan pada jari-jari tangan maupun kaki dan pada kasus kekurangan Vitamin B12 yang berat dapat menyebabkan kerusakan saraf. ${ }^{15}$

\section{Analisis Hubungan Antara Asupan Vitamin B1, B6 dan B12 Dengan Dysmenorrhea}

Berdasarkan hasil uji analisis Spearman anatara variabel asupan Vitamin B1, B6 dan B12 dengan kejadian dysmenorrhea, diperoleh $\mathrm{p}<0,05$ dan $r$ negatif oleh karena itu dapat disimpulkan bahwa terdapat hubungan yang signifikan dengan arah hubungan negatif. Arah hubungan negatif menunjukan bahwa semakin tinggi asupan Vitamin B1, B6 dan B12 maka semakin rendah skor dysmenorrheanya.

Hasil penelitian yang dilakukan di MA Nurul Ulum Munjungan antara asupan Vitamin B1 dengan kejadian dysmenorrhea $(p=0.008)$ dengan nilai korelasi $(r=-$ 0.493), hasil antara Vitamin B6 dengan kejadian dysmenorrhea $(p=0.015)$ dengan nilai korelasi $(r=-$ 0.458 ), sedangkan hubungan antara asupan Vitamin B12 dengan kejadian dysmenorrhea $(p=0.005)$ dengan nilai korelasi $(r=-0.520)$. Kemudian setelah dilakukan analisis mendalam menggunakan Uji Regresi Linier diperoleh hasil bahwa faktor yang paling mempengaruhi kejadian dysmenorrhea di MA Nurul Ulum Munjungan adalah asupan Vitamin B1 dengan nilai $(p=0.008)$ dan nilai korelasi $(r=-0.509)$. sehingga dapat diartikan Vitamin B1 merupakan zat gizi mikro yang paling berpengaruh di MA Nurul Ulum Munjungan.

Hasil dari analisis yang dilakukan di SMAN 8 Kota Malang, menunjukkan hasil yang hampir mirip yakni terdapat hubungan yang signifikan antara asupan Vitamin B1, B6 dan B12 yang ditunjukkan dengan nilai $(p<0.05)$ dan arah hubungan negatif. Pada hasil uji 
Spearman yang dilakukan untuk melihat hubungan antara Vitamin B1 dengan kejadian dysmenorrhea $(p=0.001)$ dengan nilai korelasi $(r=-$ 0.432), hasil antara Vitamin B6 dengan kejadian dysmenorrhea $(p=0.003)$ dengan nilai korelasi $(r=-$ 0.384 ), sedangkan hubungan antara asupan Vitamin B12 dengan kejadian dysmenorrhea $(\mathrm{p}=0.000)$ dengan nilai korelasi $(r=-0.466)$. Kemudian setelah dilakukan analisis mendalam menggunakan Uji Regresi Linier diperoleh hasil bahwa faktor yang paling mempengaruhi kejadian dysmenorrhea di SMAN 8 Kota Malang adalah asupan Vitamin B12 dengan nilai $(p=0.000)$ dan nilai korelasi $(r=-0.471)$. sehingga dapat diartikan bahwa zat gizi mikro yang paling berpengaruh di SMAN 8 Kota Malang adalah Vitamin B12.

Pada penelitian Husseinlou (2014) menunjukkan adanya hubungan yang signifikan antara Vitamin B1 dengan kejadian dysmenorrhea. Pada penelitian tersebut responden yang diberikan tablet Vitamin B1 memiliki nilai derajat dysmenorrhea lebih rendah dibandingkan dengan responden yang diberi placebo dengan nilai $(p<0.001)$. Penelitian lainnya mengatakan bahwa Vitamin B1 dapat mengurangi gejala dysmenorrhea malalui fungsi koenzim dalam metabolisme karbohidrat dan cabang utama asam amino yang berperan penting dalam mengobati beberapa masalah fisiologis seperti mual, muntah, mengurangi depresi, kelelahan, dysmenorrhea, kram otot dan kecemasan. ${ }^{12}$

Penelitian lain yang dilakukan Zafari (2011) menunjukkan adanya pengaruh dari pemberian tablet Vitamin B1 dalam mengobati dysmenorrhea degan nilai $(p=0.000)$. Vitamin B1 memiliki peranan dalam hamatopoiesis, metabolisme karbohidrat, aktivitas saraf pada otot sehingga dapat memberikan efek dalam menutunkan kontraksi otot rahim. Vitamin B1 adalah obat yang aman karena angka kejadian komplikasinya rendah. ${ }^{16}$

Konsumsi Vitamin B1 yang berlebih tidak akan menimbulkan bahaya keracunan. Jika mengonsumsi Vitamin B1 secara berlebihan dari yang dianjurkan, maka Vitamin B1 otomatis dieksresi melalui urin. Sedangkan konsumsi Vitamin B6 yang belebihan selama berbulan-bulan akan nenyebabkan kerusakan pada saraf yang permanen, dimulai dengan kesemutan pada kaki, kemudian mati rasa pada tangan dan akhirnya tubuh tidak mampu bekerja. Ketika kerusakan pada saraf terjadi bisa menimbulkan kram pada beberapa bagian tubuh, dimana kram merupakan salah satu gejala dari dysmenorrhea. ${ }^{17}$

Selaras dengan Vitamin B1 yang memiliki efek dalam meringankan kejadian dysmenorrxhea primer, Vitamin B6 dalam penelitian yang dilakukan Dabal (2014) menunjukkan adanya hubungan yang signifikan dari Vitamin B6 yang dapat menurunkan derajat keparahan dysmenorrhea. Pada penelitian lain yang dilakukan oleh Motesharee (2013) pada 60 perempuan non-atlet, didapatkan hasil yang signifikan bahwa pemberian tablet Vitamin B6 40mg mampu menurunkan keluhan fisik dan psikologi dari dysmenorrhea. ${ }^{18,19}$

Berdasarkan penelitian yang dilakukan Bente Deutch dan kawan- 
kawan, pemberian minyak ikan dan pemeberian minyak ikan dengan Vitamin B12 pada perempuan Danish yang mengalami dysmenorrhea menunjukkan bahwa pemberian suplementasi minyak ikan dengan Vitamin B12 lebih signifikan mengurangi tingkat dysmenorrhea. ${ }^{20}$

Minyak ikan dan Vitamin B12 yang diberikan kepada perempuan yang mengalami dysmenorrhea selama 3 bulan menunjukkan adanya konversi dari asam linileic menjadi dihomo-gamma-linolenic acid pada sampel darah mereka. Selain itu terdapat penurunan dari anti-inflamatory eikasanoid $\mathrm{PGE}_{1}$ asam arakidonat, prekursor proinflamasi $\mathrm{PGE}_{2 .}{ }^{21}$

Vitamin B12 merupakan Vitamin yang penting untuk menjaga kesehatan sel saraf dan membantu dalam produksi dari DNA dan RNA. Vitamin B12 bekerja bersama Vitamin B9 yang juga disebut asam folat, untuk memproduksi sel darah merah dan membatu zat besi bekerja lebih efektif di dalam tubuh. Folat dan B12 bekerjasama untuk memproduksi

Sasenosylmethionine (SAMe) guna meningkatkan fungsi imun dan suasana hati.

Beberapa penelitian

menjelaskan bahwa kejadian dysmenorrhea tidak hanya dipengaruhi oleh asupan makanan saja. Namun ada beberapa faktor lainnya seperti faktor biologi, perilaku atau gaya hidup, dan faktor sosial. Dalam penelitian ini faktorfaktor tersebut tidak diteliti sehingga peneliti tidak bisa menyimpulkan secara langsung kejadian dysmenorrhea pada siswi di MA Nurul Ulum Munjungan dan SMAN 8 Kota Malang.
Dari penelitian yang dilakukan, didapatkan satu zat gizi mikro yang memiliki hubungan paling berpengaruh dengan kejadian dysmenorrhea dari masing-masing sekolah. Zat gizi mikro yang memiliki hubungan penting dengan kejadian dysmenorrhea di MA Nurul Ulum Munjungan adalah Vitamin B1. Sedangkan di SMAN 8 Kota Malang zat gizi mikro yang paling berpengaruh adalah Vitamin B12. $\mathrm{Hal}$ ini dapat terjadi karena adanya pebedaan jenis makanan yang dikonsumsi oleh responden di kedua sekolah. MA Nurul Ulum Munjungan merupakan sekolah yang terletak di daerah pesisir sedangkan SMAN 8 Kota Malang merupakan sekolah yang terletak di daerah perkotaan. Sumber Vitamin B1 didapatkan dari biji-bijian, ikan laut seperti ikan tuna, dan kacang-kacangan seperti kacang merah dan kedelai. Dalam hasil wawancara yang dilakukan oleh enumerator diketahui bahwa di MA Nurul Ulum Munjungan bahan makanan seperti beras, ikan tuna, hati ayam, hasil olahan kedelai lebih sering dikonsumsi. Meskipun MA Nurul Ulum Munjungan merupakan daerah pesisir, namun hasil pertanian sangat melimpah ruah sehingga sangat mudah dalam memperoleh bahan makanan tersebut dan harganya pun murah.

Sumber dari Vitamin B12 berasal dari hati sapi, daging, olahan susu, hati ayam, dan hasil laut seperti ikan, kerang, dan udang .Dari hasil wawancara yang dilakukan ternyata responden dari SMAN 8 Kota malang lebih banyak mengonsumsi hati sapi, daging, dan hasil laut terutama udang. Responden dari daerah perkotaan memiliki pola makan lebih bervariasi, hal ini dikarenakan 
bahan-bahan makanan tersebut mudah didapatkan dan mayoritas masyarakatnya mampu membeli bahan makan tersebut. ${ }^{21}$

\section{Analisis Uji beda}

Penelitian ini menggunakan uji beda Mann-Whitney untuk melihat perbedaan asupan Vitamin B1, B6 dan B12 dari kedua sekolah tersebut. Hasil penelitian ini menunjukkan bahwa tidak ada beda asupan nutrisi yang dikonsumsi oleh MA Nurul Ulum Munjungan dengan SMAN 8 Kota Malang. Tidak adanya perbedaan dari asupan bahan makanan yang mengandung Vitamin B1, B6 dan B12 antara di MA Nurul Ulum dan di SMAN 8 Kota Malang dikarenakan pemilihan bahan makanan harian yang relatif sama. Ketersediaan bahan makanan antara di daerah Munjungan dan di Malang hampir sama. Vitamin B1 yang paling sering dikonsumsi responden berasal dari nasi, olahan kedelai, kacang hijau, susu dan kacang-kacangan. Bahan makanan sumber Vitamin B6 yang paling sering dikonsumsi oleh responden adalah udang, sayur bayam dan pisang. Sedangkan bahan makanan sumber Vitamin B12 yang paling sering dikonsumsi oleh responden dari kedua sekolah antara lain telur ayam, daging ayam, tahu, dan tempe.

Meskipun tidak terdapat perbedaan asupan Vitamin B1, B6 dan B12 antara MA Nurul Ulum Munjungan dengan SMAN 8 Kota Malang tetapi zat gizi mikronutrien yang memiliki pengaruh terhadap kejadian dysmenorrhea pada masing-masing sekolah berbeda. Zat gizi mikro yang paling berpengaruh di MA Nurul Ulum Munjungan adalah Vitamin B1 sedangkan di SMAN 8 Kota Malang zat gizi mikro yang paling berpengaruh adalah Vitamin B12.

\section{SIMPULAN}

Pada penelitian ini terdapat perbedaan antara asupan vitamin B1, B6 dan B12 dengan kejadian dysmenorrhea di MA Nurul Ulum Munjungan Kabupaten Trenggalek dan di SMAN 8 Kota Malang. Defisiensi vitamin B yang memiliki pengaruh terhadap tingkat keparahan dysmenorrhea di MA Nurul Ulum Munjungan adalah vitamin B1, sedangkan defisiensi vitamin B yang paling berpengaruh dengan tingkat keparahan dysmenorrhea di SMAN 8 Kota Malang adalah vitamin B12. Meskipun Vitamin B yang paling berpengaruh dari kedua sekolah berbeda tetapi dari hasil analisa data yang telah dilakukan dalam penilitian tidak ada beda terkait asupan makanan yang mengandung vitamin B1, B6 dan B12 anatara MA Nurul Ulum Munjungan dengan SMAN 8 Kota Malang.

\section{DAFTAR PUSTAKA}

1. Sherwood, L., (2011). Fisiologi Manusia. Jakarta: EGC

2. Proverawati, A., (2009). Menarche Menstruasi Pertama Penuh Makna. Nuha Medika, Yogyakarta.

3. Dawood, M., Yusoff., (2006) Primary Dysmenorrhea Advances in Pathogenesis Management. The American College of Obstetricians and Gynecologist

4. Shoeb, M., Kota V.R., (2012), Anti-inflammatory Affects of Benfothiamine Are Mediated Trough The Regulation of The 
Arachnoic Acid Pathway In Macrophages. Free Radical Biology and Medicine. Elsevier.

5. Adhie, RP., (2006). Kadar Aktivitin A pada Kehamilan Trimester II Sebagai Prediktor Pre-eklamsia. Tesis. Program Pasca Sarjana Megister IImu Biomedik dan Pendidikan Dokter Spesialis I Obstetri Ginekologi, Fakultas Kedokteran Universitas Diponegoro, Semarang.

6. Kobzar, G., mardla V., Ratsep I and Samel N., (2009), Effect of Vitamin B6 Vitamers on Platelet Aggregation. Platelet

7. Departemen Kesehatan RI. (2013). Angka Kecukupan Gizi yang Dianjuran bagi Bangsa Indonesia. http://www.gizi. depkes. go.id (diakses tanggal 12 Maret 2018).

8. Sukmajati,

RP., (2015). Hubungan Asupan Zat Gizi Mikro dan Komposisi Lemak Tubuh Dengan Tingkat Kebugaran Mahasiswa di UKM Sepakbola UNY. Skripsi. Program Studi S1 Gizi, Fakultas IImu Kesehatan Universitas Muhammadiyah Surakarta.

9. Muizzah, L., (2013). Hubungan Antara Kebugaran Dengan Status Gizi dan Aktivitas Fisik Pada Mahasiswi Program Studi Kesehatan Masyarakat UIN Syariat Hidayatullah Jakarta Tahun 2013. Skripsi. Program Studi Kesehatan Masyarakat Fakultas Kedokteran dan IImu Kesehatan, Universitas Islam Negeri Syarif Hidayatullah Jakarta

10. Valevski, AF., (2011). Journal of Complementary and Alternative Medicine. Topical Review Article. Israel.
11. Aryanti, SD., (2016). Hubungan Antara Asupan vitamin $B(B 1, B 6)$ Dengan Kejadian Sindrom Pramenstuasi Pada Siswi SMA Brawijaya Smart School Malang. Skripsi. Program Studi IImu Gizi Kesehatan, Fakultas Kedokteran Universitas Brawijaya, Malang.

12. Abdullahifard,S., Koshkak, AR., Moazamiyanfar, R., (2014). The Effects of Vitamin $B 1$ on Ameliorating The Premenstrual Syndrome Symptoms. Global Journal of Health Science. Jahrom University of Medical Science Jahrom. Iran.

13. Syatrian, S., P. Astrianac A., 2010. Konsumsi Makanan dan Kejadian Anemia pada Siswi Selah satu SMP di Kota Makasar. Jurnal Kesehatan Masyarakat Nasional vol. 4. Makasar.

14.Sefaya, KT., (2017). Pengaruh pendidikan Gizi Terhadap Pengetahuan Gizi dan Tingkat Kecukupan Gizi Terkait Pencegahan Anemia pada Remaja. Jurnal Kesehatan Masyarakat. Semarang: FKM Univertas Diponegoro

15. Ko, SH., Ko SH., Ahn YB., Song $\mathrm{KH}$., Han KD., et al, (2014) Association of vitamin B12 deficiency and metformin use in patients with type 2 diabetes. $J$ Korean Med Sci.

16.Zafari,Mandana.,Aghamohamma dy A., Tofoghi M. Comparing the effect of vitamin B1 (vit. B1) and ibuberofen on the treatment of primary dysmenorhea. African Journal of Pharmacy and Pharmocology. 2011, 5(7):874878

17. Almatsier, S., (2009). Prinsip Dasar IImu Gizi. Gramedia Pustaka Utama, Jakarta. 
18. Al-Dabal, B.K., Koura, M.R., AlSowielem, L.S., \& Barayan, S.S. Dysmenorrhea and associated risk factors among university students in eastern province of Saudi Arabia. Journal of Medicine \& Society. 2014,12:25

19. Motesharee,E., Rahimi, E., Asadi, N., Jafari,M., Rafati, FM., Mehbodi, M. Effects of Flexibility Exercise and Supplement Vitamin B6 on Primary Dysmenorrhea in Female NonAthletes. Armaghane danesh. 2013, 18 (7): 509-519

20. Bente,D., Eva, BJ., Jens, CH. Menstrual Discomfort In Danish Women Reduced By Dietary Supplements Of Omega-3 Pufa and B12 (Fish Oil Or Seal Oil Capsules). Elsevier Inc, 2000, 20(5): 621-631

21. Hansen, SO., UB. Knudsen. Endometriosis,dysmenorrhea and diet. European Journal of Obstetrics \& Gynecology and Reprodaductive Biology. 2013,162-171

22. Kusnadi., (2008). Keberdayaan Nelayan dan Dinamika Ekonomi Pesisir. Ar-Ruzz Media, Jember 